\title{
An Initial Classification of Neotropical Water Mites (Acari: Hydrachnidia) Based on Habitat Preferences
}

\author{
Hugo R. Fernández ${ }^{1}$ and Odile Fossati-Gaschignard ${ }^{2}$ \\ ${ }^{1}$ CONICET, Facultad de Ciencias Naturales, Instituto Miguel Lillo, Miguel Lillo 205, 4000 Tucuman, Argentina \\ ${ }^{2}$ Maison des Sciences de l'Eau, 300 Avenue Emile Jeanbrau, 34095 Montpellier Cedex 5, France
}

Correspondence should be addressed to Hugo R. Fernández, hrfe@csnat.unt.edu.ar

Received 11 March 2010; Revised 8 July 2010; Accepted 2 June 2011

Academic Editor: Patricia Mosto

Copyright $\odot 2011$ H. R. Fernández and O. Fossati-Gaschignard. This is an open access article distributed under the Creative Commons Attribution License, which permits unrestricted use, distribution, and reproduction in any medium, provided the original work is properly cited.

\begin{abstract}
Existing classifications of benthic and interstitial freshwater invertebrates are described and discussed. A classification is proposed for southern neotropical (south of latitude S 15) water mites in relation to their life style and habitat preferences. The classification includes planktonic, superficial, benthic, thermal, and subterranean forms. The diversity of the Hydrachnidia family and genera (22 families, 97 genera, and 521 species) is then analyzed using the new classification. Ubiquitous stygobites deserve special consideration because they move through ecotone zones and tolerate extreme conditions. Water mite communities from a northwestern Argentinean stream were first described using a surber net and consequently considered as benthic. Nineteen Hydrachnidia species (from benthic to stygobite) were collected and classified. The vertical distribution observed during the year confirmed the permanent presence of benthic Hydrachnidia, even during the first flood, which is of special importance in running waters. The functional classification we propose will facilitate comparison of fauna from different areas that have different faunistic composition but may have similar functional distribution.
\end{abstract}

\section{Introduction}

The role of meiofauna $(<500 \mu \mathrm{m})$, including water mites, in ecosystems (for the processing of organic matter, as a part of the food webs and as a component of biodiversity) makes their study important, but this group of invertebrates is underappreciated from a taxonomic and functional standpoint $[1,2]$. In addition, with the exception of a few studies [3-6] in South America, knowledge has barely progressed beyond the stage of describing local water mite fauna. However, taxonomic lists have recently been published for South America in general [7] and for Argentina in particular [8].

Functional approaches used for fauna living in the sediments were synthetically discussed by Claret et al. [9]. Although water mites present a great variety of forms and ecological preferences, they have been ignored or considered all together in a group (Acari) in all the existing functional classifications for freshwater invertebrates. This is not only due to lack of knowledge but also to the difficulties of water mites taxonomy. Insecta systematics is globally well established but Hydrachnidia systematics is still the subject of discussion [2]. Moreover, taxa categories may differ between these invertebrates groups, making it difficult for an entomologist to fully understand Hydrachnidia diversity beyond of the nomenclatural code. But the main problems in accounting for the ecology of Hydracarina in aquatic communities are the lack of specialists of this group and the difficulties involved in identification [1].

Classifications based on habitat preferences and on the resulting behavioral, physiological, and morphological specialization are particularly useful for regional and intercontinental comparisons (e.g., [10]). Recent ecological considerations such as life traits are difficult to apply when the biological characteristics of species are poorly documented $[9,11]$. Di Sabatino et al. [1] summarized the ecological characteristics of lotic water mites but did not propose synthetic classifications or life traits. Moreover, nearly all their examples came from temperate zones.

The tropical Andes are one of the main hotspots for biodiversity in the world [12], and unexplored habitats 
in this area represent promising subjects of study $[8,13$, 14]. Northwestern Argentina is a heterogeneous area for Hydrachnidia, and unexpected new forms have been found in interstitial habitats in this region [15-19]. Almost all interstitial water mites described in Neotropical regions were studied in the southern parts of South America (south of latitude S 15, which corresponds to the northern part of Bolivia).

The purposes of this paper are (1) to classify South American water mites following the existing systems for stygofauna, and complementing it for superficial forms, (2) to apply our new classification to published ecological data from other areas, and (3) to demonstrate its potential by applying it to old and new data from Argentina. Starting from systematic and ecological knowledge, this functional typology clarifies some poorly defined aspects of the ecology of river water mites.

\section{Existing Classifications of Freshwater Invertebrates}

The most detailed existing classification for benthic and interstitial invertebrates recognizes different types of organisms: Stygoxene, Stygobite (ubiquitous and phreatobytes), and Stygophile [9, 20]. Stygoxene taxa are epigean while stygobite taxa are strictly interstitial (Hydrachnidia have no cave or karst habitants confirmed) or ubiquitous. Between these groups, stylophiles are occasional or permanent hyporheos. Occasional hyporheos are invertebrates with a mandatory epigean phase while permanent hyporheos do not have this mandatory epigean phase. Rare amphibians, which have a long interstitial phase and a short aerial phase, have been described (e.g., Plecoptera, [21]).

Another general classification has been proposed for intermittent stream fauna [22]. Permanent subsurface river biotopes were split in two categories according to depth (shallow hyporheic, above a depth of $50 \mathrm{~cm}$ and phreatic, below a depth of $50 \mathrm{~cm}$ ). We had difficulties linking Gibert's and Boulton's classifications because they were based on very different aspects. As a simplification, we propose to differentiate Boulton's "shallow hyporheos" as stygoxene and occasional stygophile species [22, 23], and to classify permanent stygophile and phreatobyte forms as "hyporheos".

In an ecological study, Boulton et al. [24] used a more functional classification of water mites. They recognized only epigean and hypogean categories based on Acarina morphology. Recently, Boulton [25] commented on the existing classifications, emphasizing the importance of stream downwelling and upwelling zones in determining the composition of hyporheos. In particular, Boulton [25] analyzed human impacts on hyporheos and potential rehabilitation strategies.

Many stygophile species of water mites have been described as hyporheic or interstitial by their authors without any other considerations $[15,26]$. Details about the type of relationship between the species and the hyporheic ecosystem are generally scarce [24]. A range of studies about the groundwater habitat preferences of water mites have been published [27-32]. They show a complex and wide range of preferences. However, no synthetic functional classification has been proposed $[1,2]$.
Hydrachnidia belong to the suborder Parasitengona. With their terrestrial sister-group Trombidium, they are characterized by their particular life-cycle, comparable to holometabolous Insecta cycles [33, 34]: a parasitic larva, two inactive pupa-like stages (protonymph and tritonymph), and active predatory deutonymph and adult stages. Hydrachnidia (adults and deutonymphs) can be identified by the absence of subdivisions of their body (except males of some Arrenurus species), the presence of four pairs of ventral coxal plates and the presence of an anterior capitulum carrying a pair of palps and a pair of chelicerae [2]. Acarina such as some Hydrozetes species (Oribatei), although aquatic, are not included in Hydrachnidia. Oribatei, called "beetle mites" by Krantz [34], are easy to recognize because they have a heavily sclerotized oval body.

From the life traits point of view, species with extreme ways of life (phreatobytes versus stygoxene) are easier to recognize because the specializations are clear. The most distinctive features of Hydrachnidia are the coloration of the body and the development of the eyes. Stygoxene species have a colored body and functional eyes, while phreatobytes species have reduced body pigmentation and ocular regression $[1,32]$. The other categories are more difficult to recognize because their characteristics lie between the two extreme types, sometimes with different evolution levels between characters. As the result of poor knowledge of watermite ecology, subterranean water mites were all classified as "permanent hyporheos" by Gibert et al. [20]. Boulton et al. [22] classified all Hydrachnidia as belonging to shallow hyporheos, except Wandesia, which was classified as phreatic, and Meramecia and Neomamersa, which were classified as inhabitants of dry channel hyporheic. During an experimental study in a subtropical Australian river, Boulton et al. [24] recognized the water mites to be epigean or hyporheic taxa.

\section{Proposed Classification}

In this paper, habitat affinities for Neotropical water mites were elaborated based on Cook $[15,26]$ and other taxonomic descriptions, previous works $[3,13,16-19,35]$, and personal observations.

An initial classification of southern Neotropical (south of latitude S 15) species of Hydrachnidia is presented in Table 1. As Hydrachnidia never develop a short epigean form in their life cycle, it does not include amphibians [20]. As Hydrachnidia have no cave or karst habitants [29,33], all stygobite Hydrachnidia are interstitial. To the five types in the classification of Gibert et al. [20], we added new types of superficial forms. Thermal species of Hydrachnidia are so specialized that we separated them from other types. Some Hydrachnidia species are known to be good swimmers and were thus considered as planktonic (e.g., Limnesia patagonica Lundblad $[3,5]$ ). This behavior is not known for all species but we considered as planktonic the species that are generally collected in open waters and have natatorial setae. We considered as superficial species those that are able to move easily within the aquatic vegetation and are seldom found in open waters. Benthic species are able to move between the sediment grains, are seldom found above 
TABle 1: Taxonomic list of Hydrachnidia present south of latitude S 15 in South America (modified from Rosso de Ferradás and Fernández, 2005), with numbers of species indicated as well as functional classification. Un-Unknown, T-Thermal, P-Planktonic, S-Superficial, B-Benthic, Sx—Stygoxene, Oh—Occasional hyporheos, Pe—Permanent hyporheos, U—Ubiquitous stygobite, Ph—phreatobyte.

\begin{tabular}{|c|c|}
\hline Superfamily/Family & Genus, number of species and functional classification \\
\hline \multicolumn{2}{|l|}{ Hydrachnidea } \\
\hline Hydrachnidae & Hydrachna $7 B$ \\
\hline \multicolumn{2}{|l|}{ Eylaoidea } \\
\hline Limnichidae & Neolimnochares 3B, Rhyncholimnochares $6 B$ \\
\hline Eylaidae & Eylais $13 P$ \\
\hline \multicolumn{2}{|l|}{ Hydryphantoidea } \\
\hline \multicolumn{2}{|l|}{ Hydrophiidae } \\
\hline Hydryphantinae & Hydryphantes $5 P / 3 B$ \\
\hline Thyadinae & Notopanisus $1 B$ \\
\hline Protziinae & Neocalonyx $12 S / 5 B$ \\
\hline Wandesiinae & Wandesia 2T/6Ph, Euwandesia $1 \mathrm{Ph}$ \\
\hline Antelothyadinae & Ankelothyas 1Un \\
\hline Hydrodromidie & Hydrodroma $4 B$ \\
\hline \multicolumn{2}{|l|}{ Rhynchohydracaridae } \\
\hline Rhynchohydracarinae & Rhynchohydracarus $2 U n / 1 B$ \\
\hline Clathrosperchontinae & Clathrosperchon 2B/1Sx, Clathrosperchonella $2 U n$ \\
\hline Thermacaridae & Thermacarus $2 T$ \\
\hline \multicolumn{2}{|l|}{ Lebertioidea } \\
\hline \multicolumn{2}{|l|}{ Sperchontidae } \\
\hline Sperchontinae & Notosperchonopsis 3B, Illiesiella $6 B$, Sperchon $5 B$ \\
\hline Apeltosperchontinae & Apeltosperchon $1 B$ \\
\hline \multicolumn{2}{|l|}{ Anisitsiellidae } \\
\hline Anisitsellidae & Anisitsiella $1 B$, Anisitsiellides 4B, Mamersellides $1 B$, Rutacarus 3U, Sigthoriella $1 U$ \\
\hline Oxidae & Oxus $2 \mathrm{P} / 4 B$, Frontipoda $13 B / 2 U n$ \\
\hline \multicolumn{2}{|l|}{ Torrenticolidae } \\
\hline Neoatractidinae & Neoatractides $2 B$ \\
\hline Torrenticolinae & Torrenticola $4 B / 1 O h$ \\
\hline \multicolumn{2}{|l|}{ Hygrobatoidea } \\
\hline \multicolumn{2}{|l|}{ Limnesiidae } \\
\hline Neomamersinae & Neomamersa $6 U$, Meramecia $2 U$ \\
\hline Tyrrelinae & Tyrrellia 5B, Neotyrrellia $4 B$ \\
\hline Neotorrenticolinae & Neotorrenticola $7 U n$ \\
\hline Protolimnesiinae & Protolimnesia (Protolimnesella) 2U, P. (Protolimnesia) 2B/1Oh/1Pe Crenolimnesia 2Un, Limnesides 1 Un \\
\hline Mixolimnesiinae & Mixolimnesia 8Pe, \\
\hline Limnesinae & $\begin{array}{l}\text { Limnesia (Allolimnesia) 2S, L. (Limnesia) 1P/5S/23B, L. (Limnesiella) 5S, L. (5 subgenus) 7S, Centrolimnesia } \\
\text { 2S, Tubophorella 1B }\end{array}$ \\
\hline Omartacaridae & Omartacarus $3 P h$ \\
\hline \multicolumn{2}{|l|}{ Hygrobatidae } \\
\hline Hygrobatinae & $\begin{array}{l}\text { Hygrobates 20B, Aspidiobates } 1 B \text {, Atractidella } 1 T / 6 B / 1 S x \text {, Atractides } 7 B / 1 O h \text {, Australiobates } 7 B \text {, Brevaturus } \\
\text { 10B, Callumobates } 1 B \text {, Camposea } 1 U \text {, Corticacarus } 41 B / 1 \text { Oh, Crenohygrobates } 1 \text { Un, Deccussobates } 2 B \text {, } \\
\text { Diamphidaxona } 3 U \text {, Dodecabates } 1 B \text {, Dubiobates 10B, Eocorticacarus } 1 B \text {, Hygrobatella 10B, Paraschizobates } \\
\text { 1S, Mapuchacarus } 1 B \text {, Megapellia } 2 B \text {, Motasia 1B, Osornobates } 1 B \text {, Schizobates } 4 B \text {, Tetrahygrobatella } 3 B \text {, } \\
\text { Zabobates } 3 B\end{array}$ \\
\hline Rhynchaturinae & Rhynchaturus $7 B$, Andesobates $1 B$, Szalayella $1 B$ \\
\hline
\end{tabular}


TABle 1: Continued.

\begin{tabular}{|c|c|}
\hline Superfamily/Family & Genus, number of species and functional classification \\
\hline Ferradasiidae & Ferradasia $1 S$ \\
\hline \multicolumn{2}{|l|}{ Unionicolidae } \\
\hline Pionatacinae & Koenikea 35S, Neumania 5S, Recifella $3 S$ \\
\hline \multicolumn{2}{|l|}{ Pionidae } \\
\hline Pioninae & Piona $8 P$ \\
\hline \multicolumn{2}{|l|}{ Aturidae } \\
\hline Frontipodopsinae & Frontipodopsis $2 B$ \\
\hline Aturinae & Aturus $1 B$, Kongsbergia $1 B$, Neoaturus $1 B$ \\
\hline Axonopsinae & Axonopsella $12 \mathrm{Oh} / 1 \mathrm{Pe}$, Axonopsis $1 \mathrm{~B}$, Lethaxonella $1 U$, Miraxonides $2 B$, Stygalbiella $1 U$ \\
\hline Albiinae & Albia $1 S$ \\
\hline Notoaturinae & Notoaturus $4 U$, Noesaturus $4 U$, Notaxona $1 B$ \\
\hline \multicolumn{2}{|l|}{ Arrenuroidea } \\
\hline Momoniidae & Momoniella $1 B$, Notomomonia $3 U$ \\
\hline Mideopsidae & Mideopsis 17S, Phreatomideopsis 1 Pe \\
\hline Krendowskiidae & Krendowskia 2B, Geayia $1 B$ \\
\hline \multirow[t]{2}{*}{ Arrenurus } & Arrenurus (Truncaturus) 4U, Arrenurus 25B, \\
\hline & Thoracophoracarus $2 B$ \\
\hline
\end{tabular}

the sediments, and are not good swimmers. Stygoxene species are benthic forms that occasionally appear in deeper zones. They are sometimes found in hyporheic samplings although they have obvious benthic characters (eyes, colour, size, shape, etc.). The other functional types (occasional hyporheos, permanent hyporheos, ubiquitous stygobites, and phreatobytes) are similar to those proposed by Claret et al. [9]. The whole typology for adults is presented in Figure 1, with examples of the main types (thermal Hydrachnidia excluded). In the following text, "superficial sensu lato (s.l.)" refers to superficial and planktonic forms.

Most Hydrachnidia develop in five stages between egg and adult. Little is known about inactive forms (prelarva, protonymph, tritonymph), which were not included in this classification. Larva are identified due to the presence of six legs instead of eight but were not included because they are seldom observed, and knowledge about their ecology is very sparse, except that they are parasites, generally of aquatic insects [33]. Deutonymphs and adults are similar morphologically except for the presence of gonopores in adults. Deuteronymphs and adults may have contrasting substrate preferences. For example, Limnesiidae nymphs are generally stygoxen while adults are benthic or even planktonic (Limnesia patagonica Lundblad). However, as little is known about deuteronymphs, they were not included in our new classification.

\section{Diversity of Hydrachnidia Found in Southern Parts of South America}

Starting from Rosso de Ferradás and Fernández [7] list, but keeping only the species that we know to be present south of northern Bolivia, we found 22 families, 97 genera and 521 species (Table 1). We classified these species following the proposed classification, except 21 species that we were unable to classify and kept as unknown.

Most of the families, genera, and species have representatives in benthic communities (Figure 2, unknown and thermal forms excluded). Families and species were more frequently classified as benthic. Moreover, more numerous superficial s.l. forms were observed than stygobitic.

Eleven families were classified exclusively within one ecological type: the two species of Thermacaridae as thermal, Pionidae and Eylaidae as planktonic, Ferradasiidae and Unionicolidae as superficial, Hydrodromidie and Hydrachnidae as well as Krendowskiidae, Limnichidae and Sperchontidae as benthic, and Omartacaridae as phreatobytes (Table 1).

Five families were classified in two ecological types. Oxidae were considered as planktonic or benthic (2 species with unknown distributions excluded). Mideopsidae were classified as superficial, with one species belonging to permanent hyporheos; Anisitsiellidae and Arrenurus were classified as benthic with few ubiquitous stygobites forms. Momoniidae were classified as ubiquitous stygobites or benthic.

Four families displayed more complex distributions (Figure 3). Hydrophiidae were classified as superficial with a significant number of species belonging to benthic or even interstitial communities. Hygrobatidae were mainly seen as benthic, with two superficial s.l. (1 planktonic and 1 superficial sensu stricto s.s.) and seven species (1 stygoxene, 2 occasional hyporheos, 4 ubiquitous stygobites). Limnesiidae were classified as benthic, with a significant number of species living above or below the strictly benthic area, including one planktonic species at the present meaning unclear 

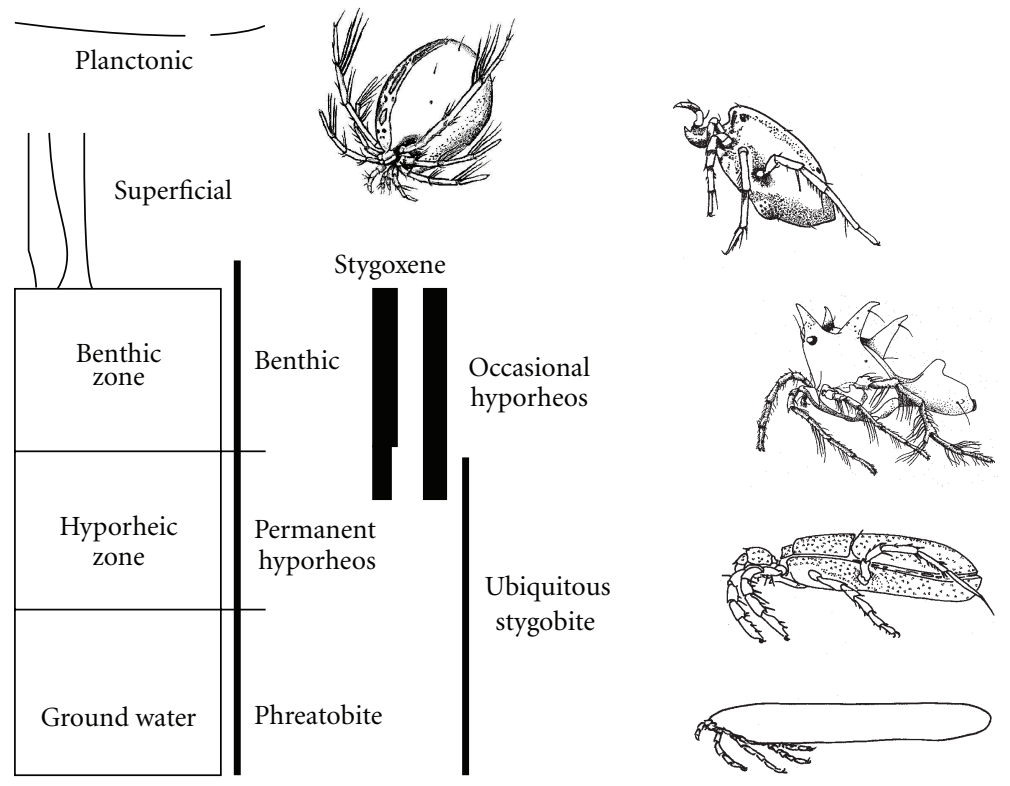

FIGURE 1: Recognized habitats in aquatic systems (mainly running water) for Hydrachnidia. The vertical lines represent the classification ranges; their width is in proportion with the number of taxa. The forms presented are, from top to bottom: Oxus sp. (Oxidae, planktonic, modified from Barr, 1973), Koenikea sp. (Unionicolidae, superficial, drawn from a photograph by Smith, Cook and Smith, 2001), Arrenurus diabolus Lundblad (Arrenurida, benthic, drawing by B. Rosso de Ferradás), Neomamersa falcipalpis Cook (Limnesiidae, ubiquitous stygobite, drawing by H. R. Fernández), and Wandesia andiana Cook (Hydryphantidae, phreatobite, drawing by H. R. Fernández).

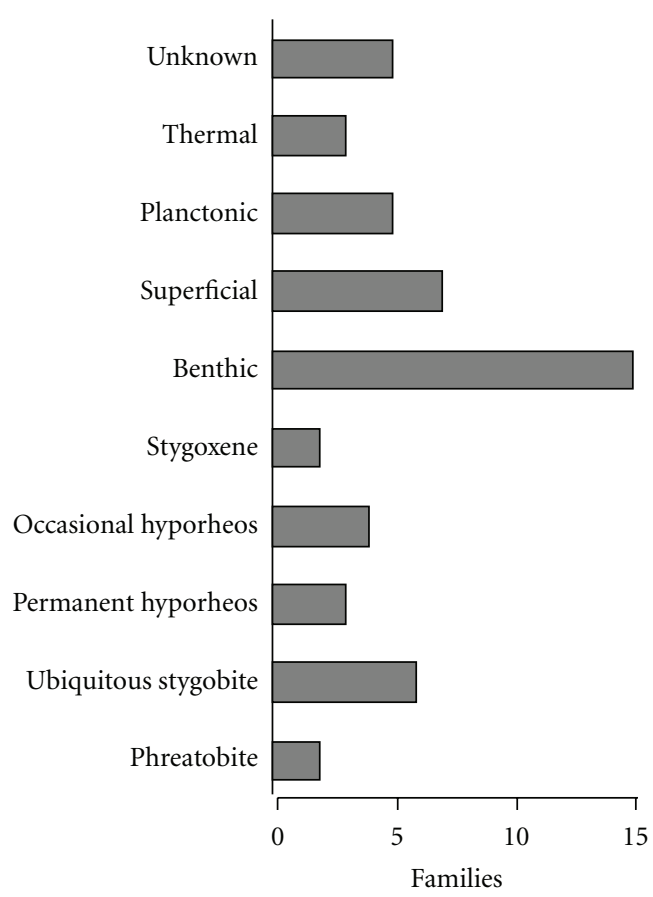

(a)

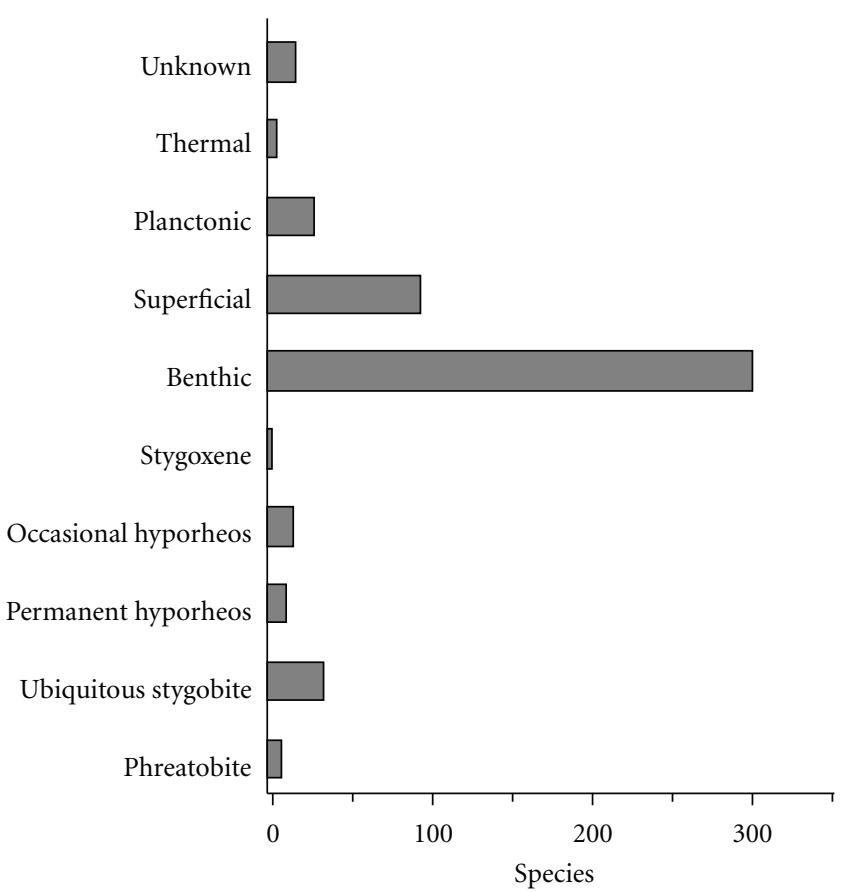

(b)

Figure 2: Functional classification for South-American (south of latitude S 15) Hydrachnidia, in numbers of families and species in each class. 


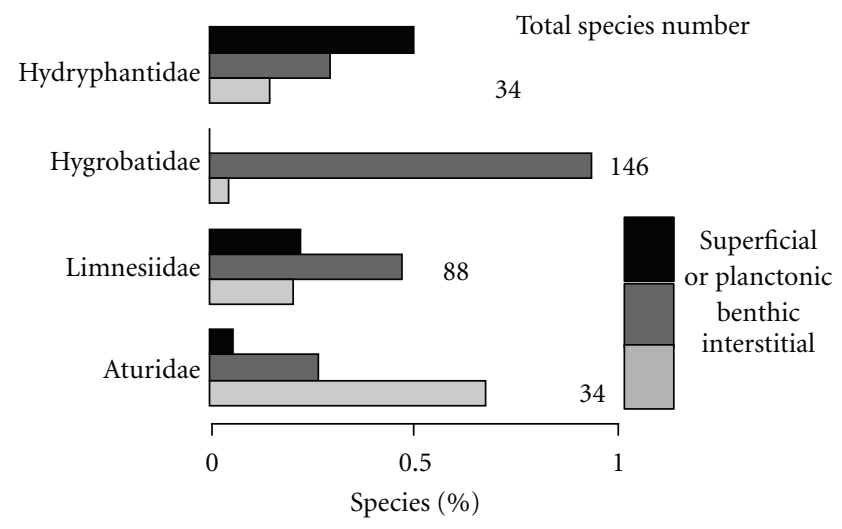

Figure 3: Percent of the main ecological forms in the four most diverse Hydrachnidia families.

$[3,5]$. Aturidae were considered as interstitial, but some species have were classified as benthic or even superficial.

\section{Extending the Conclusions of Published Descriptions}

Using the proposed typology at generic level, we reanalyzed some published ecological results. Particularly interesting are the Boulton et al. [24] and Boulton and Stanley [23] papers because they identified water mites. These papers, as well as others, for example, Boulton et al. [36] and Stanley and Boulton [37], described the spatial distribution, taxonomic composition, and fauna dynamics of the hyporheos of Sonoran desert streams (Arizona, USA). In a synthetic view, these authors recognized four hyporheic biotopes: shallow hyporheic, phreatic, parafluvial (including the shoreline phreatic zone recognized by Pennak and Ward [38] and dry channel hyporheic).

We checked these functional subsets of desert ecosystems (Boulton et al. [22]) using the present classification, based on the habitat preferences of water mites (Table 1). As observed by Boulton and Stanley [23], the presence of Wandesia sp. (a phreatobyte) characterizes the phreatic biotope. The presence of Atractides spp. in hyporheic water samples is more difficult to analyze. This genus has sometimes been considered as a hyporheic visitor [1]. The inclusion of Atractides sinuatipes among stylophiles (occasional hyporheos) corresponds to a more precise description. This can be explained by considering that under certain conditions, for example, during the drying process, as a stygophile form, this species seeks refuge in the shallow hyporheic biotop. The hyporheic zone thus functions as a refuge, protecting the invertebrates from superficial drought and not only from superficial floods, which are more frequently observed [24].

Some stygobite ubiquitous forms such as Meramecia and Neomamersa are difficult to classify because they are able to move from the benthic zone to deeper zones. As was correctly observed by Boulton and Stanley [23], these water mites tolerate extreme conditions typical of drying hyporheic zones. In this case, ubiquitous stygobites are euryoecious forms that inhabit a variety of hypogean biotopes, including interfaces, and tolerate habitat variations. Considering Meramecia species as ubiquitous forms helps explain the unclear patterns observed by Boulton and Stanley [23] and the differences observed within shallow hyporheos assemblage. The observation of Meramecia, Chironomidae larvae, Copepod, and Cladocera in the same habitat is mainly the result of chance sampling because the association is only temporary. Meramecia spp. are ubiquitous stygobites while Chironomidae larvae, Copepod, and Cladocera are globally better described as occasional hyporheos (stylophiles). However, inside Copepod and Cladocera may exist different ecological preferences. In this case, more accurate identifications would favour better habitat attributions.

Arenohydracaridae do not exist in South America. However, the association between Arenohydracarus and Meramecia, demonstrated through their common correlation with the number of days since surface flow was lost above a well [23, Table 1, page 33], shows that Arenohydracarus are ubiquitous stygobites, which completes the description given by Boulton and Stanley [23]. The absence of correlation between Atractides and the number of days since surface flow was lost above a well might have been expected because Atractides spp. are generally benthic species, even if one South American species was classified as stygophile.

Based on all these observations, we can affirm that the dry channel hyporheos is a less valid biotop than the others. It is not as valid because it is temporary, but most of all because the water mites considered within this biotop are, in fact, ubiquitous stygobites and euryoecious forms that can populate hyporheic zones when superficial water has disappeared.

\section{Use of the Typology-Examples from Argentina}

An annual study of hyporheic fauna in the subtropical mountains of Tucumán (Argentina), Fernández and Palacios [35], using Bou-Rouch method, now enables some species to be classified as permanent hyporheos and stygobites (ubiquitous) and some benthic species with nymphs inhabiting the hyporheic zone species to be classified as stygoxenes. Only one phreatic species (Wandesia andiana Cook) was present in the samples during the extreme drought period.

Four different sites were occasionally studied in the same subtropical mountains of Tucumán during the 19891990 period (Table 2). Samples were taken using a surber net $(250 \mu$ mesh size) and communities were thus first considered as benthic. Nineteen Hydrachnidia species were collected and classified from benthic to stygobites, using our classification (Figure 4). The vertical distribution observed over the year demonstrated the permanent presence of benthic Hydrachnidia in the benthic zone, even during the maximum precipitation period in February. Stygobiont forms were generally abundant in these samples, mainly at the end of the flooding season (e.g., stygobites forms in May) and throughout the dry season. The San Javier River, a small affluent partially located in a protected area, had the more diverse Hydrachnidia fauna, while the main stream (Lules River) had lower abundances and diversities, even in its upstream La Hoyada site. In a recent study in the Lules River, 
TABle 2: Hydrachnidia from Lules Streams (Tucumán, Argentina) 1989-1990.

\begin{tabular}{|c|c|c|c|c|c|c|c|c|c|c|c|c|c|c|c|c|c|c|c|c|c|c|c|c|c|c|}
\hline & Тур & May & & & & July & & & & Oc & ober & & & & ecemb & & & & ruary & & & April & & & & \\
\hline & & SJ & LH & LJ & $\mathrm{L}$ & SJ & $\mathrm{LH}$ & LJ & $\mathrm{L}$ & SJ & LH & LJ & $\mathrm{L}$ & SJ & $\mathrm{LH}$ & LJ & $\mathrm{L}$ & SJ & $\mathrm{LH}$ & LJ & $\mathrm{L}$ & SJ & LH & LJ & $\mathrm{L}$ & Sum \\
\hline $\begin{array}{l}\text { Torrenticola } \\
\text { columbiana }\end{array}$ & $\mathrm{Oh}$ & 17 & 2 & 2 & 2 & 13 & 0 & 0 & 2 & 24 & 0 & 1 & 3 & 14 & 0 & 15 & 0 & 0 & 0 & 0 & 0 & 25 & 1 & 2 & 4 & 127 \\
\hline $\begin{array}{l}\text { Rhycholimnochares } \\
\text { expansiseta }\end{array}$ & B & 2 & 1 & 1 & 0 & 0 & 0 & 0 & 1 & 0 & 0 & 0 & 0 & 1 & 0 & 0 & 0 & 0 & 1 & 0 & 0 & 0 & 0 & 3 & 0 & 10 \\
\hline $\begin{array}{l}\text { Clathrosperchon } \\
\text { punctatus }\end{array}$ & Sx & 0 & 0 & 0 & 0 & 0 & 0 & 0 & 0 & 0 & 0 & 0 & 0 & 0 & 0 & 1 & 0 & 0 & 0 & 0 & 0 & 0 & 0 & 0 & 0 & 1 \\
\hline Limnesia sp. & B & 0 & 0 & 0 & 0 & 0 & 0 & 0 & 0 & 0 & 1 & 0 & 0 & 0 & 0 & 0 & 0 & 0 & 0 & 0 & 0 & 0 & 0 & 0 & 0 & 1 \\
\hline $\begin{array}{l}\text { Protolimnesia } \\
\text { interstitialis }\end{array}$ & $\mathrm{U}$ & 1 & 2 & 0 & 0 & 2 & 0 & 0 & 0 & 0 & 0 & 0 & 0 & 0 & 0 & 0 & 0 & 0 & 0 & 0 & 0 & 0 & 0 & 0 & 0 & 5 \\
\hline $\begin{array}{l}\text { Protolimnesia } \\
\text { setifera }\end{array}$ & $\mathrm{Oh}$ & 0 & 1 & 0 & 0 & 0 & 0 & 0 & 0 & 0 & 0 & 0 & 0 & 0 & 0 & 0 & 0 & 0 & 0 & 0 & 0 & 0 & 0 & 0 & 0 & 1 \\
\hline $\begin{array}{l}\text { Neomamersa } \\
\text { mexicana }\end{array}$ & $\mathrm{U}$ & 0 & 1 & 0 & 0 & 1 & 0 & 1 & 1 & 0 & 0 & 0 & 0 & 0 & 0 & 0 & 0 & 0 & 0 & 0 & 0 & 0 & 0 & 0 & 0 & 4 \\
\hline Corticacarus smithi & B & 3 & 0 & 0 & 0 & 1 & 3 & 0 & 0 & 0 & 1 & 0 & 0 & 12 & 0 & 0 & 0 & 0 & 0 & 0 & 0 & 0 & 0 & 0 & 0 & 20 \\
\hline $\begin{array}{l}\text { Corticacarus } \\
\text { brassanus }\end{array}$ & B & 0 & 0 & 0 & 0 & 0 & 0 & 0 & 0 & 0 & 0 & 1 & 0 & 0 & 0 & 1 & 0 & 0 & 0 & 0 & 0 & 0 & 0 & 0 & 0 & 2 \\
\hline $\begin{array}{l}\text { Tetrahygrobatella } \\
\text { argentinensis }\end{array}$ & B & 2 & 0 & 0 & 0 & 0 & 4 & 0 & 0 & 0 & 0 & 0 & 0 & 0 & 0 & 0 & 0 & 0 & 0 & 0 & 0 & 0 & 0 & 0 & 1 & 7 \\
\hline $\begin{array}{l}\text { Hygrobates } \\
\text { ampliatus }\end{array}$ & B & 0 & 0 & 0 & 0 & 0 & 1 & 0 & 0 & 0 & 0 & 0 & 0 & 0 & 0 & 0 & 0 & 0 & 0 & 0 & 0 & 0 & 0 & 0 & 0 & 1 \\
\hline $\begin{array}{l}\text { Hygrobates } \\
\text { brasiliensis }\end{array}$ & B & 0 & 0 & 0 & 0 & 1 & 0 & 0 & 0 & 0 & 0 & 0 & 0 & 0 & 0 & 0 & 0 & 0 & 0 & 0 & 0 & 0 & 0 & 0 & 0 & 1 \\
\hline $\begin{array}{l}\text { Atractides } \\
\text { brasiliensis }\end{array}$ & B & 1 & 0 & 2 & 1 & 0 & 0 & 2 & 0 & 0 & 0 & 0 & 0 & 4 & 0 & 0 & 0 & 0 & 0 & 0 & 0 & 0 & 0 & 0 & 0 & 10 \\
\hline $\begin{array}{l}\text { Atractides } \\
\text { sinuatipes }\end{array}$ & B & 7 & 1 & 1 & 1 & 16 & 0 & 0 & 0 & 9 & 0 & 0 & 0 & 13 & 0 & 11 & 0 & 0 & 0 & 0 & 0 & 0 & 0 & 0 & 0 & 59 \\
\hline $\begin{array}{l}\text { Atractidella } \\
\text { porophora }\end{array}$ & B & 5 & 2 & 2 & 2 & 0 & 0 & 0 & 0 & 10 & 0 & 0 & 0 & 9 & 0 & 0 & 0 & 0 & 0 & 0 & 0 & 0 & 0 & 0 & 0 & 30 \\
\hline $\begin{array}{l}\text { Dodecabates } \\
\text { dodecaporus }\end{array}$ & B & 1 & 0 & 2 & 0 & 1 & 3 & 4 & 0 & 4 & 0 & 2 & 0 & 0 & 0 & 0 & 1 & 0 & 1 & 0 & 0 & 0 & 0 & 0 & 0 & 19 \\
\hline $\begin{array}{l}\text { Diamphidaxona } \\
\text { yungasa }\end{array}$ & $\mathrm{U}$ & 0 & 2 & 0 & 0 & 1 & 0 & 0 & 0 & 0 & 0 & 0 & 0 & 0 & 0 & 0 & 0 & 0 & 0 & 0 & 0 & 0 & 0 & 0 & 0 & 3 \\
\hline $\begin{array}{l}\text { Stygalbiella } \\
\text { tucumanensis }\end{array}$ & $\mathrm{U}$ & 0 & 0 & 0 & 0 & 0 & 1 & 0 & 0 & 0 & 0 & 0 & 0 & 0 & 0 & 0 & 0 & 0 & 0 & 0 & 0 & 0 & 0 & 0 & 0 & 1 \\
\hline $\begin{array}{l}\text { Axonopsella } \\
\text { argentinensis }\end{array}$ & $\mathrm{Pe}$ & 0 & 0 & 0 & 0 & 0 & 0 & 0 & 0 & 0 & 0 & 0 & 0 & 1 & 0 & 0 & 0 & 0 & 0 & 0 & 0 & 0 & 0 & 0 & 0 & 1 \\
\hline Sum & & 39 & 12 & 10 & 6 & 36 & 12 & 7 & 4 & 47 & 2 & 4 & 3 & 54 & 0 & 28 & 1 & 0 & 2 & 0 & 0 & 25 & 1 & 5 & 5 & 303 \\
\hline
\end{tabular}

it was possible to again identify, in a multivariate analysis, a group of taxa associated with a stygobiontic form of life [39]. This grouping was previously observed in another study [40]. It is characterized by (considering only arthropods) one stygobite phreatobyte (Bogidiella, Crustacea: Amphipoda), ubiquitous stygobites (Neomamersiinae and Protolimnesia water mites), and occasional stylophiles (insect Empididae larvae).

\section{Discussion}

The diversity of water mite forms enables them to be classified in almost all of the existing functional groups. Water mites however have no cave habitants, which is strange for a group with very adaptable characteristics [29, 33]. Although it was not recognised in previously published descriptions $[9,20]$, a broad group of ubiquitous stygobite Hydrachnidia exists. Those forms were globally considered as permanent hyporheos and thus stygophile. Only the most spectacular forms, such as species of Omartacarus (Omartacaridae) and Wandesia (Hydrophiidae Wandesiinae), were then classified as subterranean. Probably only Crustacea Amphipoda display a comparable diversity of forms.

Species classification is easy when the morphological adaptations are obvious (colour and presence or absence of eyes, i.e.). The real problems are the intermediate forms that occupy transitional or ecotonal zones. The hyporheic zone is a clear example of ecotone [21], and the fauna that inhabit it 


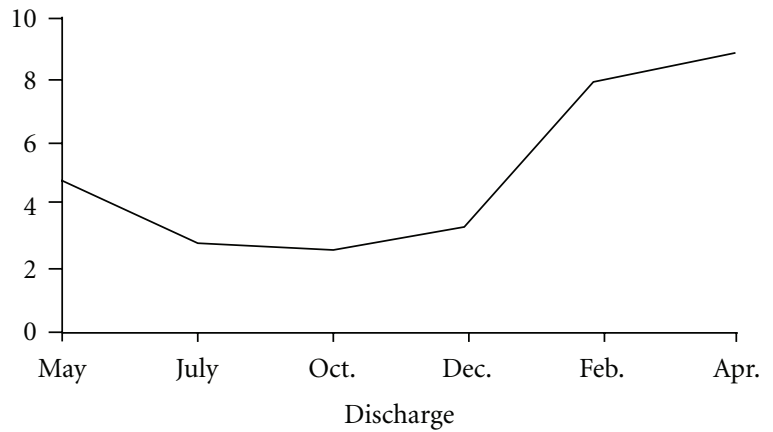

(a)

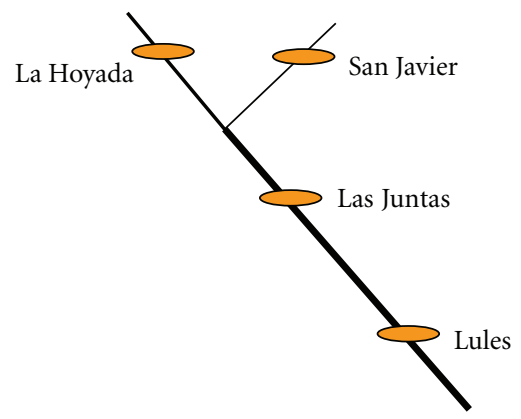

(c)

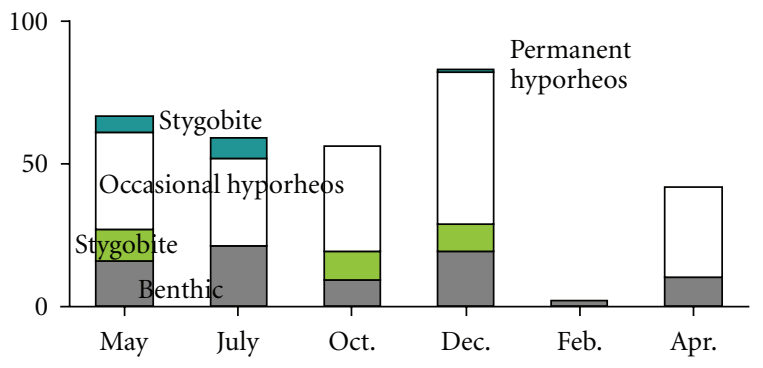

(b)

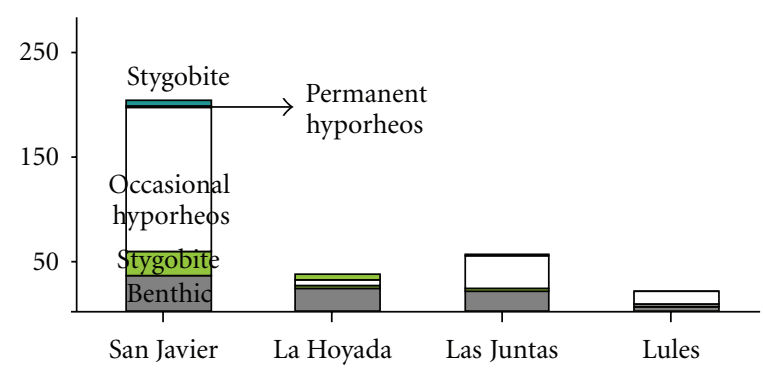

(d)

Figure 4: Example of use of the Hydrachnidia functional classification (Lules streams, Tucumán, Argentina). Left-top: discharge ( $\mathrm{m}^{3} \mathrm{~s}^{-1}$ ) Lules River during the year. Left-bottom: esquematization of the sampled rivers and sites.

must be euryoecious to survive varied habitat conditions, or restricted to a narrow area.

Water mites are a variable group $[1,2]$ and functional classifications are difficult to establish, especially among ubiquitous taxa. Ubiquitous stygobites tolerate wide ranges of conditions which explains their abundance in hyporheic zones during hydraulic stress [23]. With better knowledge, the species classified as ubiquitous stygobites in this classification could probably be included in more specialized groups. Possibly all these species have more specialized vertical distributions and could be classified as phreatobionts or permanent hyporheic even if knowledge about their ecology is not sufficient to confirm it.

The ubiquitous stygobite group includes many transitional forms. Between the benthic zone and groundwater, and especially in the hyporheic zone, one observes species with a diverse combination of morphological changes related to an increasingly subterranean way of life [32]. Ubiquitous stygobite water mites are an interesting group, though not clearly delimited, because they are frequently collected by nonspecific methods $[15,18,26,41]$. Seeing Meramecia species as ubiquitous forms helps explain the unclear patterns obtained and the differences observed within shallow hyporheos assemblages by Boulton and Stanley [23].
On the other hand, collections using methods such as digging in submerged gravel bars affect the ecological criteria for subterranean attributions $[17,26,32]$. In this situation, the diversity in aquatic sediment is frequently underestimated $[41,42]$.

Among water mites, a gradient of adaptations can be observed from planktonic to totally subterranean. The presence of water mites in planktonic communities is a wellknown fact in America [5], although they are often not observed on other continents [2]. Superficial s.l. water mites are probably the most diverse type because they include planktonic and superficial s.s. forms and include many other forms that are occasionally found in aquatic vegetation. South America is rich in standing waters and aquatic vegetation [43], which might explain the diversity of superficial forms of Neotropical Hydrachnidia. These forms can explore leaf packs, macrophytes (represented by curved lines in Figure 1), and filamentous algae such as Cladophora spp. They combine characteristics of benthic forms (good walkers) and swimmers (some natatorial setae).

In the upper sediment levels, families or subfamilies include species belonging to different categories. As an example, Protolimnesia (Limnesiidae) have representatives in all categories except phreatobytes. Among freshwater invertebrates, 
few examples are known of this type of ecological diversity within one genus. The systematics of water mites, however, is very peculiar and sometimes specialists do not agree. Family or genus for Mollusca, Crustacea, or Insecta specialists might mean something different for acarologists.

Adaptations to phreatic environments are sometimes observed in one or a few species within a family or even an order. Among Crustacea, the genus Patagonaspides (Patagonaspididae) is an inhabitant of phreatic groundwater and differs from all the other South American species of Anaspidacea that inhabit hyporheic environments [44]. Among water mites, some families or subfamilies, generally the most specialized (phreatobytes), are unigeneric and related to only one habitat. As examples, all the species Omartacarus and Wandesia are phreatobytes. In these genera, depthrelated morphological evolution was strong enough to drive taxonomical classification. However, except for these old stygobiont forms $[32,45]$, the taxonomic classification has little in common with the ecological classification.

The proposed classification is a promising tool to explore meiofauna communities. It may help clarify biodiversity studies in subterranean fauna $[41,42]$. Sometimes, species identification cannot explain some observations better than genera or family identification. In these cases, the use of functional classifications may improve our understanding of the communities observed. It is possible to use this classification to improve the interpretation of ecological data from subtropical South America or even from a wider territory. However, the possible use of shifting habitats by species along a latitudinal gradient, as some authors suggest [46], makes its application more risky at more northern latitudes.

Focused studies are needed on water mite taxonomy. Some groups, like Aturidae, are a mix of dubious forms that could probably be included in other families. For similar reasons, Cook [47] called Anisitsiellidae a "dumping ground". Moreover, many families include genera that could be moved to other groups. A new approach may even be needed in the case of some families. For example, Goldschmidt [48] stated that Limnesiidae and Anisitsiellidae should be included in the same family after the discovery of new forms, seen as intermediary between the two families, which were first described in 1900 (Limnesiidae Thor) and 1910 (Anisitsiellidae Koenike). A more frequent chosen option is to expand the morphological characteristics of a family or a subfamily to include new forms. For example, Cook [26] redefined Notoaturinae (Aturidae) to include a new African form and Notaxona ochiepus Besch (from Chile), which were previously assigned to Axonopsinae [47].

The functional classification proposed here will facilitate the comparison of fauna from different areas that have different faunistic composition but may have similar functional distribution. Considering that environmental pressures on organisms are the same around the world, we expect to find equivalent forms in distant areas when the corresponding habitat exists. Our knowledge about one group (water mites) enabled us to propose this functional classification which should now be tested using other groups or the invertebrate community as a whole.

\section{Conclusions}

This is the first functional classification ever presented for superficial, benthic, and interstitial water mites. Any benthic or stygoic study that includes water mites should consider using this classification to improve interpretation of the community as a whole. It will also facilitate the comparison of fauna from different areas and help understand the exchange processes between surface and subsurface areas via the interstitial zone.

This classification is provisional and invites future studies to validate or refute the functional classifications described. Promotion of collaboration between taxonomists and ecologists opens the door to a more functional perspective of aquatic communities.

\section{Acknowledgments}

The authors thank D. L. Strayer for comments and language assistance on the earlier manuscript, Dr. A. Valdecasas, Dr. C. Claret and Dr. M-J Dole-Olivier for valuable comments and D. Goodfellow for linguistic advices. They also thank two anonymous reviewers for their constructive comments.

\section{References}

[1] A. Di Sabatino, R. Gerecke, and P. Martin, "The biology and ecology of lotic water mites (Hydrachnidia)," Freshwater Biology, vol. 44, no. 1, pp. 47-62, 2000.

[2] I. M. Smith, D. R. Cook, and B. Smith, "Water mites (Hydrachnida) and other Arachnids," in Ecology and Classification of North American Freshwater Invertebrates, J. Thorp and A. Covich, Eds., pp. 551-659, Academic Press, San Diego, Calif, USA, 2nd edition, 2001.

[3] B. Rosso de Ferradás, J. Kaisin, and A. S. Bosnia, "Seasonal variation of density and biomass of Hydracarina (Acari) in a North-Patagonian reservoir (Neuquén, Argentina)," Studies on Neotropical Fauna and Environment, vol. 22, pp. 133-127, 1987.

[4] V. F. Matveev, C. C. Martinez, and S. M. Frutos, "Predatoryprey relationships in subtropical zooplankton: water mite against cladocerans in an Argentine lake," Oecologia, vol. 79, no. 4, pp. 489-495, 1989.

[5] E. G. Balseiro, "The role of pelagic water mites in the control of cladoceran population in a temperate lake of the Southern Andes," Journal of Plankton Research, vol. 14, no. 9, pp. 12671277, 1992.

[6] H. R. Fernández, "Structure of water mite taxocoenoses in two northwestern Argentinean subtropical subcatchments," Systematic and Applied Acarology, vol. 8, pp. 55-66, 2003.

[7] B. Rosso de Ferradás and H. R. Fernández, "Elenco y biogeografía de los ácaros acuáticos (Acari, Parasitengona, Hydrachnidia) de Sudamérica," Graellsia, vol. 61, pp. 181-224, 2005.

[8] H. R. Fernández and B. Rosso de Ferradas, "Hydrachnidia," in Biodiversidad de Artrópodos Argentinos, L. E. Claps,, G. Debandi, and S. Roig-Juñent, Eds., vol. 2, pp. 117-127, Editorial Sociedad Entomológica Argentina, Mendoza, Argentina, 2008.

[9] C. Claret, P. Marmonier, M. J. Dole-Olivier, M. Creuzé Des Châtelliers, A. J. Boulton, and E. Castella, "A functional classification of interstitial invertebrates: supplementing measures 
of biodiversity using species traits and habitat affinities," Archiv für Hydrobiologie, vol. 145, no. 4, pp. 385-403, 1999.

[10] B. Statzner, B. Bis, S. Dolédec, and P. Usseglio-Polatera, "Perspectives for biomonitoring at large spatial scales: a unified measure for the functional composition of invertebrate communities in European running waters," Basic and Applied Ecology, vol. 2, no. 1, pp. 73-85, 2001.

[11] O. Fossati, P. Dumas, V. Archaimbault et al., "Deriving life traits from habitat characteristics: an initial application for neotropical invertebrates," Journal de Recherche Océanographique, vol. 28, pp. 158-162, 2003.

[12] N. Myers, R. A. Mittermeler, C. G. Mittermeler, G. A. B. Da Fonseca, and J. Kent, "Biodiversity hotspots for conservation priorities," Nature, vol. 403, no. 6772, pp. 853-858, 2000.

[13] B. Rosso de Ferradás and H. R. Fernández, "Arrenurus Dugès (Acari: Prostigmata: Parasitengona) fitotelmicos de Venezuela," Entomotrópica, vol. 16, pp. 53-60, 2000.

[14] H. R. Fernández and B. Rosso de Ferradás, "Hidrácaros del Altiplano Boliviano: La cuenca alta del río Suchez," Physis, vol. 58, no. 2, pp. 9-36, 2001.

[15] D. R. Cook, "Neotropical water mites," Memoirs of the American Entomological Institute, vol. 31, pp. 1-645, 1980.

[16] H. R. Fernández, "Acaros Intersticiales del Noroeste Argentino IV. Análisis filogenético y biogeográfico de Omartacarus Cook (Acari, Omartacaridae): una primera aproximación," Revista Sociedad Entomologica Argentina, vol. 52, pp. 107-117, 1993.

[17] H. R. Fernández, "Acaros Intersticiales del Noroeste Argentino III. Nuevos aportes morfológicos sobre especies hiporreicas del Protolimnesia Lundblad y Diamphidaxona Cook," Physis (1991), vol. 49, pp. 23-30, 1994.

[18] H. R. Fernández, "Acaros hiporreicos de Argentina: nuevos datos sobre Neomamersinae Lundblad (Limnesiidae)," Physis (2000), vol. 58, pp. 21-28, 2001.

[19] H. R. Fernández, "Interstitial water mites of Argentina: Omartacarus Cook (Omartacaridae) and Meramecia Cook (Limnesiidae) (Acari: Hydrachnidia)," Zootaxa, vol. 73, pp. 16, 2002.

[20] J. J. Gibert, J. A. Stanford, M. J. Dole-Olivier, and J. V. Ward, "Basic attributes of groundwater ecosystems and prospects for research," in Groundwater Ecology, J. Gibert, D. L. Danielopol, and J. A. Stanford, Eds., pp. 7-40, Academic Press, San Diego, Calif, USA, 1994.

[21] J. A. Stanford, J. V. Ward, and B. K. Ellis, "Ecology of the alluvial aquifers of the Flathead River, Montana," in Groundwater Ecology, J. Gibert, D. L. Danielopol, and J. A. Stanford, Eds., pp. 367-390, Academic Press, San Diego, Calif, USA, 1994.

[22] A. J. Boulton, H. M. Valett, and S. G. Fisher, "Spatial distribution and taxonomic composition of the hyporheos of several Sonoran Desert streams," Archiv für Hydrobiologie, vol. 125, pp. 37-61, 1992.

[23] A. J. Boulton and E. H. Stanley, "Hyporheic processes during flooding and drying in a Sonoran Desert stream. II. Faunal dynamics," Archiv für Hydrobiologie, vol. 134, no. 1, pp. 27-52, 1995.

[24] A. Boulton, M. Harvey, and H. Proctor, "Of spates and species: responses by interstitial water mites to simulated spates in a subtropical Australian river," Experimental and Applied Acarology, vol. 34, no. 1-2, pp. 149-169, 2004.

[25] A. J. Boulton, "Hyporheic rehabilitation in rivers: restoring vertical connectivity," Freshwater Biology, vol. 52, no. 4, pp. 632-650, 2007.
[26] D. R. Cook, "Water mites from chile," Memoirs of the American Entomological Institute, vol. 42, pp. 1-356, 1988.

[27] L. Szalay, "Über die Hydracarinen der unterirdischen Gewässer," Hydrobiologia, vol. 2, no. 2, pp. 141-179, 1949.

[28] C. Motas, "Sur les Acariens phréatiques, leur distribution géographique, leur Origine," Zoologischer Anzeiger, vol. 168, pp. 325-350, 1962.

[29] E. Angelier, "Remarques sur la répartition de la faune dans le milieu interstitiel hyporhéique," Zoologischer Anzeiger, vol. 168, pp. 351-356, 1962.

[30] E. Angelier, M. L. Angelier, and J. Lauga, "Recherches sur l'écologie des Hydracariens (Hydrachnellae, Acari) dans les eaux courantes," Annales de Limnologie, vol. 21, pp. 25-64, 1985.

[31] J. Schwoerbel, "Die Bedeutung des Wassermilben für die biozönotische Gliederung," Verhandlungen der Internationalen Vereinigung für Theorestische und Angewandte Limnologie, vol. 14, pp. 355-361, 1961.

[32] J. Schwoerbel, “Acari: Hydrachnellae," in Stygofauna Mundi, L. Botosaneanu, Ed., pp. 652-696, E.J. Brill, Leiden, The Netherlands, 1986.

[33] A. Di Sabatino, P. Martin, R. Gerecke, and B. Cicolani, "Hydrachnidia (water mites)," in Freshwater Meiofauna: Biology and Ecology, S. D. Rundle, A. L. Robertson, and J. M. Schmid-Araya, Eds., pp. 105-133, Backhuys, Leiden, The Netherlands, 2002.

[34] G. W. Krantz, A Manual of Acaralogy, OSU Book Stores Inc., Corvallis, Ore, USA, 1970.

[35] H. R. Fernández and A. N. Palacios, "La fauna intersticial hiporreica de dos ríos de montaña del noroeste de Argentina," Rivista di Idrobiología, vol. 28, pp. 231-246, 1989.

[36] A. J. Boulton, S. E. Stibbe, N. B. Grimm, and S. G. Fisher, "Invertebrate recolonization of small patches of defaunated hyporheic sediments in a Sonoran Desert stream," Freshwater Biology, vol. 26, no. 2, pp. 267-277, 1991.

[37] E. H. Stanley and A. J. Boulton, "Hydrology and the distribution of hyporheos: perspectives from a mesic river and a desert stream," Journal of North American Benthological Society, vol. 12, pp. 79-83, 1993.

[38] R. W. Pennak and J. V. Ward, "Interstitial faunal communities of the hyporheic and adjacent groundwater biotopes of a Colorado mountain stream," Archiv für Hydrobiologie, Supplement, vol. 74, pp. 356-396, 1986.

[39] H. R. Fernandez, F. Romero, and E. Domínguez, "Intermountain basins use in subtropical regions and their influences on benthic fauna," River Research and Applications, vol. 25, no. 2, pp. 181-193, 2009.

[40] H. R. Fernández, F. Romero, M. Peralta, and L. Grosso, "La diversidad del zoobentos en ríos de montaña del noroeste de Argentina: comparación entre seis ríos," Ecología Austral, vol. 11, no. 1, pp. 9-16, 2001.

[41] H. R. Fernández, "Does wrong procedence assignment lead to underestimates in groundwater biodiversity?" Ecologia Austral, vol. 14, no. 1, pp. 77-81, 2004.

[42] M. A. Palmer, A. P. Covich, B. J. Finlay et al., "Biodiversity and ecosystem processes in freshwater sediments," Ambio, vol. 26, no. 8, pp. 571-577, 1997.

[43] E. A. Esteves, Fundamentos de Limnologia, Editora Inteciência/ FINEP, Rio de Janeiro, Brasil, 1988.

[44] L. E. Grosso and M. Peralta, "Patagonaspides gen. n.; P. sandroruffoi sp. n. (Crustacea, Syncarida) first phreatobite species of a new anaspidacean family discovered in Patagonia with cladistic analysis of Stygocaridinea (Anaspidacea)," Bolletino 
del Museo Civico di Storia Naturale di Verona, vol. 26, pp. 105$118,2002$.

[45] A. Petrova, "Origine et évolution des hydracariens souterrains," Stygologia, vol. 5, pp. 249-251, 1990.

[46] A. G. Valdecasas, "A review of the water mite Hungarohydracarus subterraneus Szalay and its subspecies (Hydrachnellae, Acari)," in Acarology VI, D. A. Griffiths and C. E. Bowman, Eds., vol. 2, pp. 971-979, Ellis Horwood Ltd, Chichester, UK, 1984.

[47] D. R. Cook, "Water mite genera and subgenera," Memoirs of the American Entomological Institute, vol. 21, pp. 1-860, 1974.

[48] T. Goldschmidt, "Environmental parameters determining water mite assemblages in Costa Rica," Experimental and Applied Acarology, vol. 34, no. 1-2, pp. 171-197, 2004. 

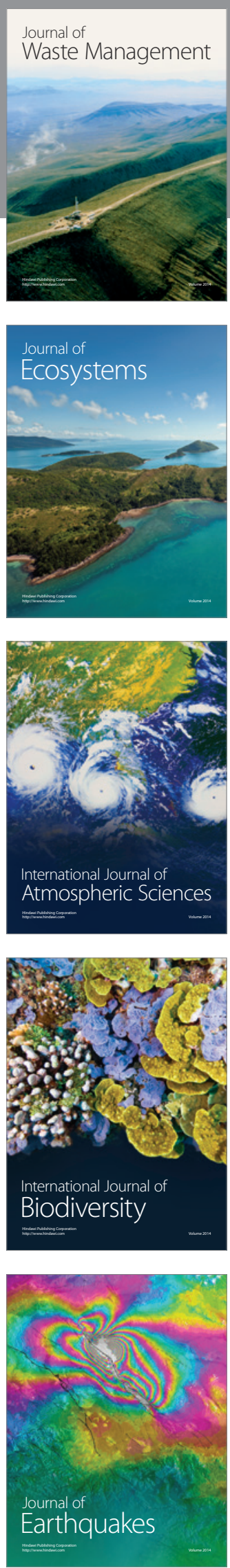
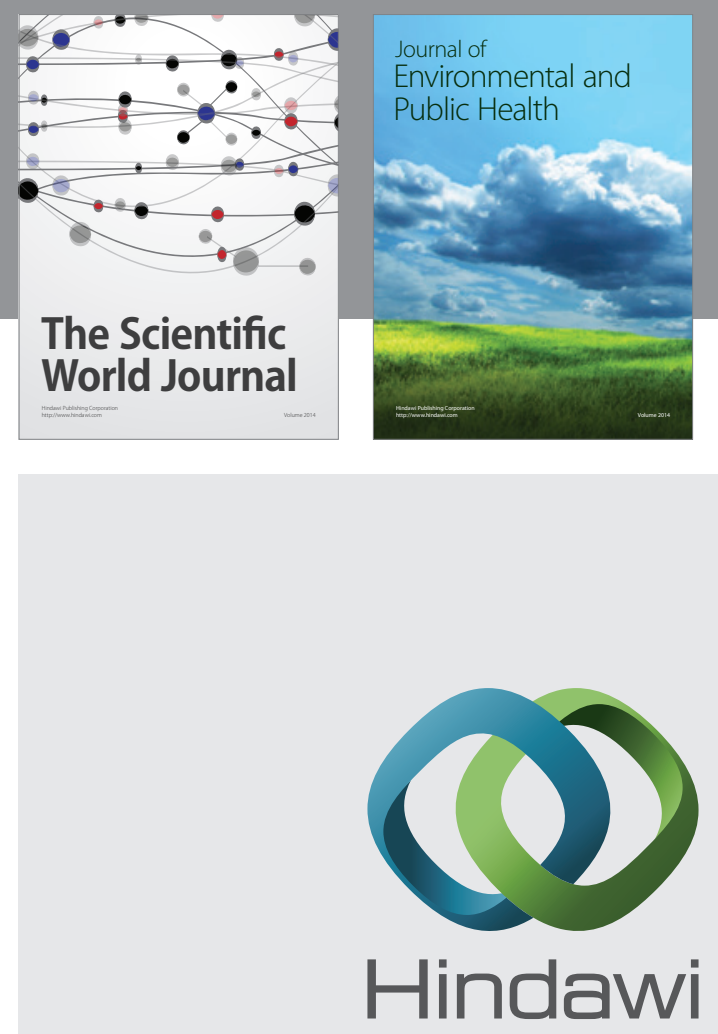

Submit your manuscripts at

http://www.hindawi.com
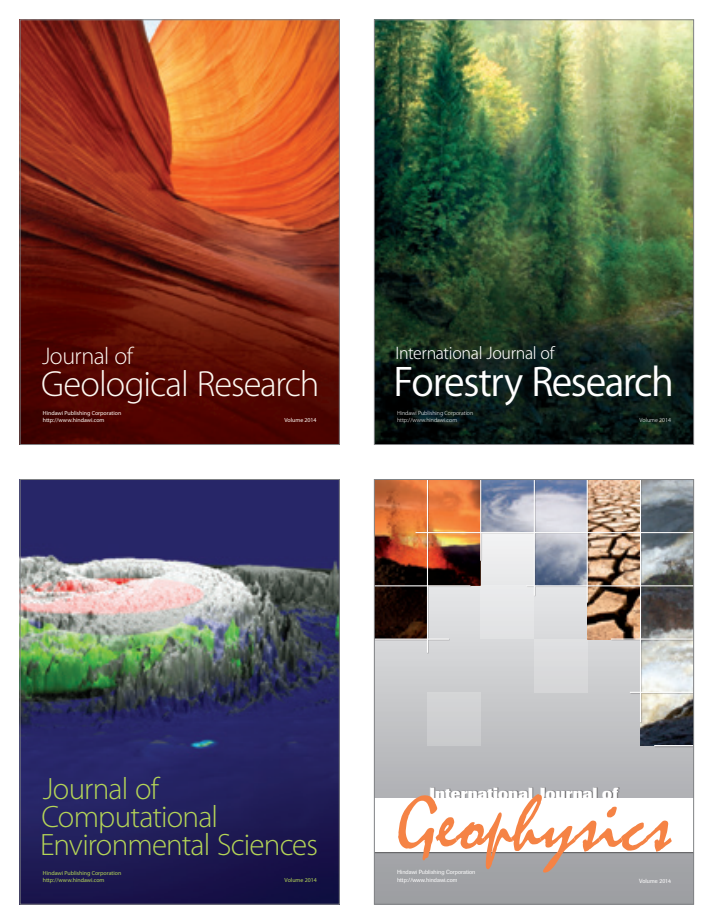
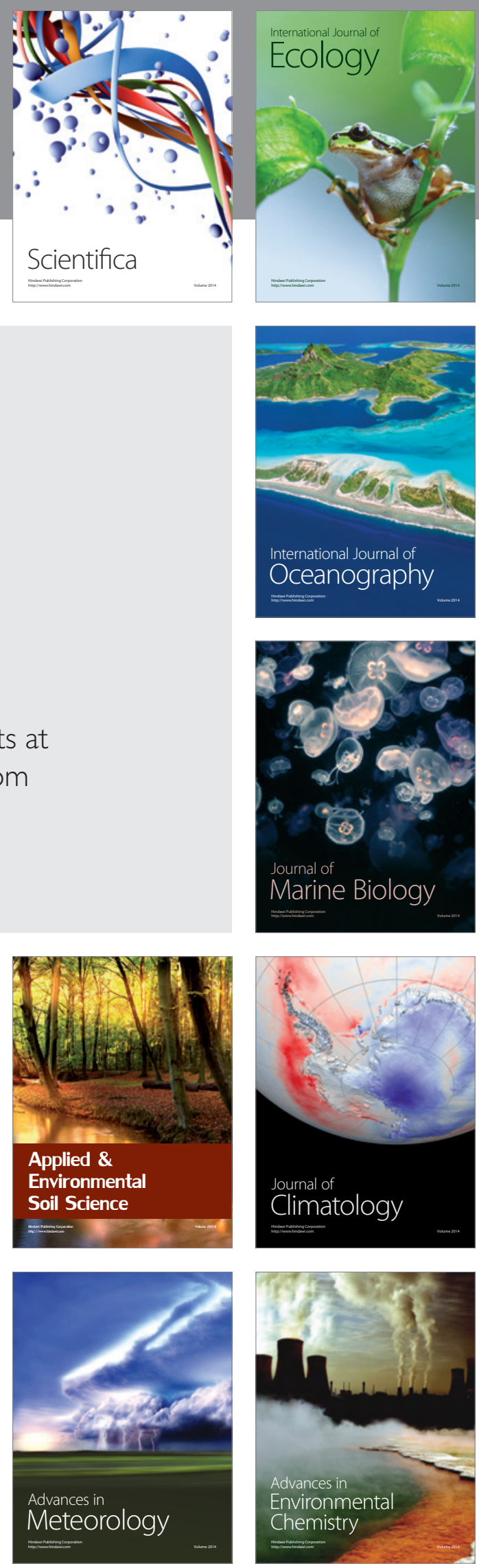